\title{
ARCHIVING THE DIGITAL RAI COLLECTION OF TRADITIONAL FOLK CULTURE
}

Ettore Pacetti, Audiovisual Archives, RAI Teche, Italy Daniela Floris, Audiovisual Archives, RAI Teche, Italy

\section{RAI Archive of Italian Popular Traditions: The Audio Collection and The Project'}

There are not two distinct stories - that of the people and that of the educated classes; there is only one story. It is the result of continuous cultural exchange, so items of cultivated origin are assimilated into the popular tradition.

Diego Carpitella

\section{I.I Introduction}

For twenty years, RAI Teche, the RAI structure of Italian Broadcast that includes all the RAI archives, has been committed to bringing to the attention of an ever-wider public the most representative components of the historical, social, and cultural evolution of our country in its collections.

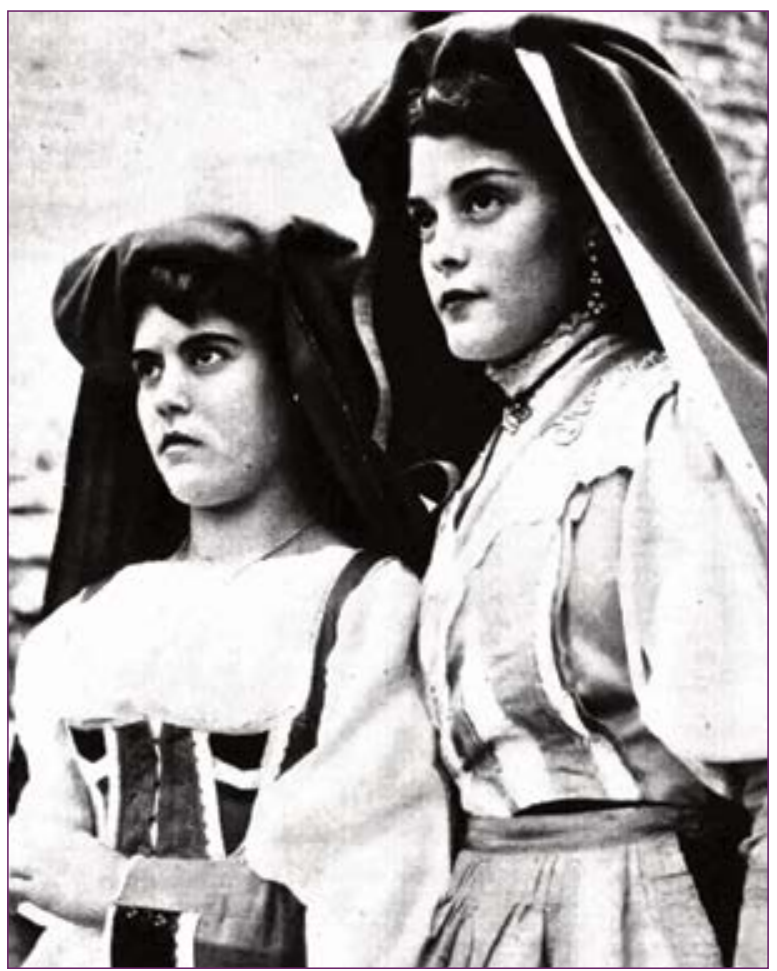

Figure I. Two young peasants of Basilicata with their typical costumes.

I This section of this co-produced paper contributed by Ettore Pacetti. 
The activity of recovering and enhancing RAl's audiovisual heritage is taking a fundamental step with the launch of a recovery project devoted specifically to Italian folklore. It is intended to highlight a significant documentary complex of research activity that marks a new era for the study of Italian folk traditions and thus becomes a compulsory passage for any possibility to understand the phenomenon.

From this first step was born the need to create a publication space-a website: http://www. teche.rai.it/archivio-del-folclore-italiano/- that would be a specific reference to a fundamental aspect of Italian cultural identity, and an effective tool for sharing and exchanging funds and resources with other audiovisual archives.

It is of particular importance to note that this collection of ethnic heritage is a consequence of the birth and development of sound and visual reproduction media and is, therefore, intimately linked to the very history of the largest Italian radio and television broadcaster.

\section{I.2 Before the existence of sound mechanical reproduction tools}

Documentation of Italian folk music was also made earlier in the late 19th and early 20th centuries by transcribing texts and melodies heard in various geographic areas, especially in Piedmont, Sicily, and Sardinia.

Some scholars began to identify the characteristics of popular art, still completely ignored. It was gradually realized that, alongside art with a story made of physical texts that traced the course of development through the centuries, a popular art survived that, in terms of visual, literary, and musical aspects, was made up of texts and music handed down through oral tradition, in which they still lived with patterns dating back to archaic formulas.

As is well known, the cultured art had a great evolution, made by the succession of different languages that have followed, opposing each other. Often, in the most radical manifestations, they have sought to affirm their supremacy over others by denying the past as a symbol of cultural backwardness and affirming the primacy of the current, which is only able to find the best language because it is more evolved. Popular art, on the other hand, has remained immobile, forced to find in this deliberate refusal of any transformation its ability to survive as an autonomous expression without being overwhelmed by the growing process of cultural unification.

Before the introduction of sound mechanical reproduction tools, the main instrument for the study of oral expression was the transcription. This operation fatally converted a language with its own original code to a style similar to that of the cultural art, eliminating the most characteristic features. The transcription exposed the inconvenience of applying to popular expression, both poetic and musical, concepts and styles typical of Western literature and music. For music, for example, the harmonic structure has become more and more limited to the distinction between major and minor, in the common idea of a predetermined "ethos" of joy for one and sadness for the other.

\section{I.3 The formation of the archive}

A formidable enhancement to the survey of oral expression came with the emergence of audiovisual and sound reproduction media. These recording media allowed people to capture the testimonies of popular art, in that originality and immediacy that sanctioned its authenticity. 
The fruit of the authentic revolution that these recording devices determined was, outside the Italian borders, the fundamental collection made in the first decades of the last century by Béla Bartók and Zoltán Kodály and devoted to Hungarian folk songs.

Based on these premises and with support from the foundation of the National Center of Popular Studies, RAI has promoted research and collecting of materials through targeted expeditions in all regions of Italy since 1947, favoring sites often excluded from educational and informational flows that circulated in major urban centers.

During these expeditions, the sound documents were recorded directly in the places and contexts of origin, avoiding the transcription that would have inevitably betrayed their authenticity.

Songs, voices, dialects, ways of speaking, and spoken inflections outlined the sound landscape of a peasant society depicted before the advent of industrialization, able to retain, in addition to the original linguistic pattern, the sense of rituals, and the sense of the works and the customs of the past ages through the songs that accompanied them. All this anthropological heritage would have been irretrievably lost if it had not been recorded in sound documents.

These expeditions were organized and directed by the great ethnomusicologist, Diego Carpitella, who engaged other great scholars who were able to combine anthropological research with ethnomusicological research, such as Ernesto De Martino, Giorgio Nataletti, and American folklorist, Alan Lomax. This collection, which has been preserved at RAI and at the National Academy of Santa Cecilia in Rome, contains about 5000 songs that are extremely representative of the various regional realities, and it is still the most impressive and relevant systematic research of Italian ethno-music heritage.

The material was identified by the National Center of Music Studies, founded by RAI Radiotelevisione Italiana and by the National Academy of Santa Cecilia in Rome. RAl funded the initiative and provided all technical means, from cars to recording equipment. The sound documents were always recorded in the places of origin between 1947 and the end of the 1960 s, and their content was censored and analyzed with rigorous scientific criteria.

The result of this vast survey is contained in the volume, Folk. Documenti sonori. Catalogo informativo delle registrazioni musicali originali edited by RAI ERI in 1977, which lists the music tracks, specifying for each of them the title, location, performer, date of recording, and form or function. The volume will be fully available on the website dedicated to Italian folklore. All documents of the collection were digitized and now are gradually published on the site of RAI Teche. 


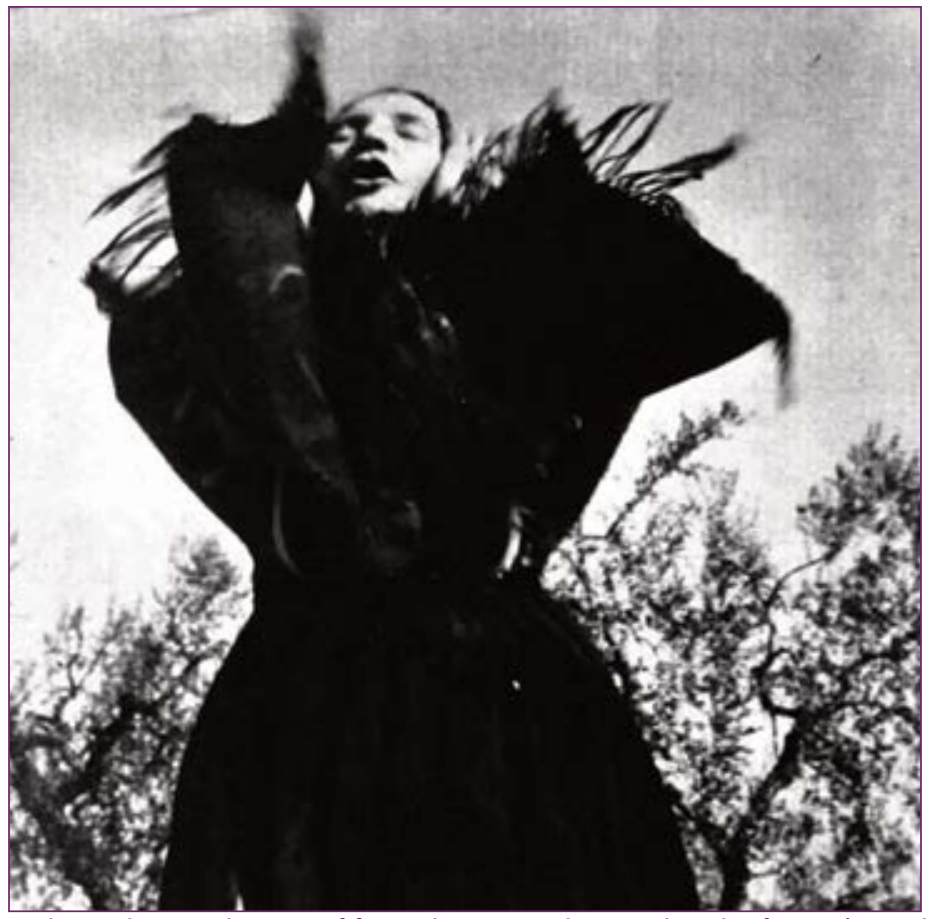

Figure 2. This photo depicts the rite of funeral weep, widespread in the farmer's world of southern Italy. To honor their dead, women gathered and wept with a special technique. Here the woman weeps in the countryside of Pisticci (Basilicata).

\section{I.4 The historical context of Italy in the mid-1950s}

It is important to mention the historical context in which this great collection was formed, and the perspective change of the radio medium compared to the fascist period. In the twenty years of fascism, radio was essentially a means of building consensus. Every aspect of it aimed to give a triumphal and celebratory image of Italy's history and life. Music programming, therefore, was essentially focused on serious and mass music and excluded forms that did not fall into these two genres, and which did not address only medium and high social classes.

The end of the war and the problems of reconstruction completely renewed the media dimension and, above all, the radio that became a tool (a propaganda vehicle) for analyzing the anthropological and cultural aspects of previously ignored social classes. 


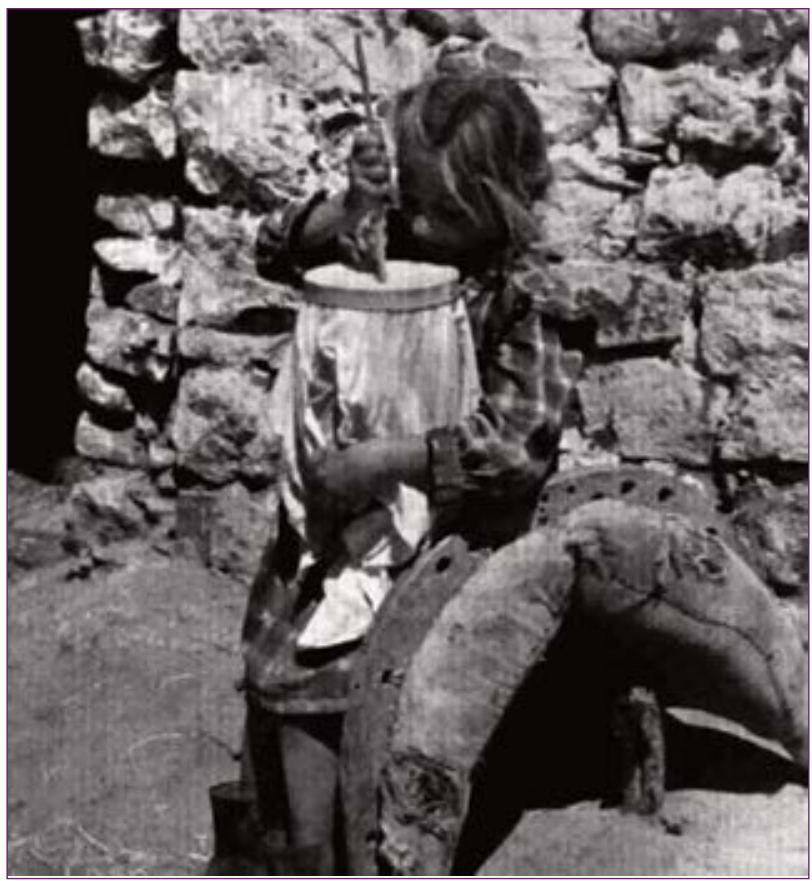

Figure 3. CUPA CUPA. A popular musical instrument typical of southern Italy made of a container covered with a cloth or membrane and a long and thin cane.

\section{I.5 Project development}

In this particular historical moment, in the middle of the last century, RAI began collecting documents of Italian folklore. Today, this heritage becomes accessible to an ever-expanding set of users through a specific area of the RAI Teche site. As far as sound records are concerned, the collection of Carpitella, Lomax, Nataletti is the most important part, but next to it there are other relevant documents. Among them is the radio documentary, Spedizione in Lucania (Expedition to Lucania), by Ernesto De Martino, broadcast in 1953, which describes a trip to one of the poorest and most depressed regions of southern Italy in the middle of the last century to analyze the traditional cultural life of peasant peoples of the region, through the study of songs, dances, poems, and tales.

In addition, there are precious audiovisual testimonials found in the television archive thanks to Daniela Floris's irreplaceable contribution, without whose expertise and passion the project would not have succeeded.

The purpose of RAI Teche is to create a portal ${ }^{2}$ devoted to the history of Italian folklore, not only music, powered by the process of finding, archiving, and digitizing audiovisual cultural heritage resources. In this way, it is possible to share these fundamental documents of the history of Italy with an ever-wider and more general audience, formed by different generations and specializations, through a simple and direct discovery system and synthetic, but rigorous, cataloging.

2 The address of the website is: http://www.teche.rai.it/archivio-del-folclore-italiano/ [Accessed 7 January 20 I8]. 


\section{The Memory of a Country Unveiled in a Radio and Television Archive: The Portal on Folklore and Popular Traditions of RAI Radiotelevisione Italiana ${ }^{3}$}

Diego Carpitella has been a pioneer of ethnomusicological research in Italy: one of the first in our country to give credibility to the science and the study of traditional music, and to understand the enormous importance of using recorded sound technology to record oral expression that could, in this way, have the possibility to survive the inevitable progress of the peasant world and of the country's non-dominant cultures.

So, with great interest (Diego Carpitella was my tutor at University La Sapienza in Rome), I started to listen to and to select the recorded materials for the implementation of the first part of this project, in which we are preparing the complete folk recordings of the Carpitella Collection to be published on the Rai Teche Portal.

In 1959, Carpitella was part of the anthropologist team, led by Ernesto De Martino, that went to Salento, Puglia, southern Italy, to collect documents on tarantism, magic, and funeral lamentation, which became the basis of fundamental texts such as The Land of Remorse: $A$ Study of Southern Italian Tarantism and Magic:A Theory from the South. Ritual weeping always has a codified and ritualized structure. It is a ritual a community has developed to appropriate a natural event, enormous and ineluctable as the death of a relative, and to develop it into a rite that makes it "Culture," or, a human phenomenon manageable by men. The ritual allows the community to overcome what De Martino described as a "crisis of presence."

On our new website for this project, we have a great variety of funeral lamentations ${ }^{4}$, not only from Salento, but also from other regions of Italy recorded by other researchers. We have documents (audio tapes and video) about the Salento also related to tarantism. De Martino with his team pointed out that the taranta puncture was nothing more than the stinging of a mythical spider, which sought to find a "cultural" remedy for situations of profound discomfort and difficulty. A reassuring and resolute cure was developed "in-house" as music therapy, with the "pizzica", played by a group composed of organetto, guitar, violin, and tambourine. With this therapy, the time of despair is coded and delimited in a timely manner and as such is tackled and resolved. ${ }^{5}$

The documents in the "Folk" collection are not just music. For example, we have the audio tape of noises and sounds recorded in Galatina on St. Paul's Day, 29 June 1959. Those who thought they were possessed by the tarantula flocked to church to pray and thank the Saint. De Martino in his The Land of Remorse explains that the phenomenon of tarantism inside the church, in which music therapy was forbidden, loses every ritual and every "order" to make room for real psychological pathological phenomena.

This section of this co-produced paper contributed by Daniela Floris.

4 For example, see: $\mathrm{http}: / / \mathrm{w} w \mathrm{w}$.teche.rai.it/20 | 4/I I/archivio-del-folclore-musicale-italiano-basilicata/ and then select document number 54 [Accessed 8 January 2018].

5 See the conversation and recordings documenting tarantism, here: http://www.teche.rai.it/1978/06/possessione-lataranta-salentinal [Accessed 8 January 2018]. 
In this particular document you can listen to screams, shouts, people knocking on the grate that protects the statue of the saint, tunes, thuds, and other attempts to simulate a therapeutic "pizzica" but without musical instruments. ${ }^{6}$

We can also find other sounds of everyday life, for example the bells of the oxen wagon carts in Sardinia, lullabies from all Italian regions, children's songs, narrative songs, or work songs.

In addition to documents from the entire Carpitella collection we decided to include all RAl programs from 1954 to 1980 that have a theme related to folklore or popular traditions. This important research, still in progress, is bringing to light very interesting materials:

- Programs related to the work of the same Diego Carpitella, who appears as a curator or participant in documentary or anthropological background investigations

- Documentaries aired with educational intent, and which today take on the testimony of a country that no longer exists.

In our archives there are also documentaries or programs relating to emigration from campaigns to cities during the era of industrialization; the social conditions of women; the peasantry world; the work of artisans in the pre-industrial age; or even on regions of the pastoral economy, such as Sardinia. ${ }^{7}$ We also have documents about ethnic minorities in Italy, and an entire collection dedicated to children's games. All documentaries are important evidence of an Italy that no longer exists or is profoundly changed.

\section{Bibliography}

Adamo, G. (1952). Musiche tradizionali in Basilicata. Le registrazioni di Diego Carpitella. Roma, Squilibri.

Agamennone, M.,V. Lombardi. (1954). Musiche tradizionali del Molise. Le registrazioni di Diego Carpitella e Alberto Mario Cirese. Roma, Squilibri.

Agamennone, M. (1989). “Etnomusicologia italiana: radici a sud. Intervista a Diego Carpitella sulla storia dell'etnomusicologia in Italia.” In Suonosud, II/4 Pp. I84I.

Agamennone, M. (2005). Musiche tradizionali del Salento. Le registrazioni di Diego Carpitella. Roma, Squilibri.

Bartok, B. (1977). Scritti sulla musica popolare. A cura di Diego Carpitella. Universale scientifica, Boringhieri.

De Martino, E. (1959). Sud e magia. Feltrinelli, Milano.

De Martino, E. (1963). La terra del rimorso. Contributo a una storia religiosa del Sud. II Saggiatore, Milano.

De Martino, E. (1996). La crisi della presenza in Basilicata. Calice.

6 Listen here: http://www.teche.rai.it/20 |4/ | |/archivio-del-folclore-musicale-italiano-puglia/ and then select document number 12 [Accessed 8 January 2018].

7 For example, see: http://www.teche.rai.it/1969/02/dentro-la-sardegna-uninchiesta-i-pastori-della-comunita-diollolail [Accessed 8 January 20।8]. 
De Martino, E. ( 1997). La fine del mondo. Contributo all'analisi delle apocalissi culturali. Einaudi, Torino.

De Martino, E. (2005). The Land of Remorse:A Study of Southern Italian Tarantism. London: Free Association Books.

De Martino, E. (2008). Morte e pianto rituale nel mondo antico. Dal lamento pagano al pianto di Maria. Universale Bollati Boringhieri.

De Martino, E. (20I5). Magic:A Theory from the South. Chicago: University of Chicago Press/ HAU Books.

Gallini, C. (2005). Ernesto de Martino e la formazione del suo pensiero. Liguori, Napoli.

Giannattasio, F. (1991).“L'attività etnomusicologica di Diego Carpitella.” In Lares, 57, pp. 93-109.

Giuriati, G. (1995).“'Italian ethnomusicology.” In Yearbook for Traditional Music, XXVII, pp. I04-I3I.

Giurati, G. (2007). Incontri di etnomusicologia. Seminari e conferenze in ricordo di Diego Carpitella. Accademia Nazionale di Santa Cecilia, Roma.

Lomax, A., Plastino, G. (2008). L'anno più felice della mia vita. Un viaggio in Italia. Il Saggiatore.

Merriam, A. (1964). The Anthropology of music. Northwestern University Press, Evanston.

Mingozzi, G. (1978). Profondo Sud.Viaggio nei luoghi di Ernesto De Martino a vent'anni da 'Sud e Magia', Feltrinelli. 